\title{
Globalization, Structural Reform, and Labour Politics in China
}

\author{
Marc Blecher \\ Oberlin College
}

\begin{abstract}
To analyze the relationship between globalization and labour protest, this paper compares labour politics in three regions: the highly globalized southeast 'sunbelt', the relatively less 'reformed', barely globalized, and decaying Manchurian rustbelt, and the broadly 'reformed' but only partially globalized and still largely domestically-oriented areas that make up most of the rest of the country, represented in this chapter by the city of Tianjin, the site of the author's field research. For each, we will identify key dimensions of labour politics. This political configuration forms our explanandum, which is fleshed out region by region. The paper then seeks the explanans of these salient similarities and differences, focusing on the key question of resistance.
\end{abstract}

\section{KEYWORDS}

China, globalization, labour politics, labour protest, Tianjin

The cheap prices of commodities are the heavy artillery with which [capitalism] batters down all Chinese walls, with which it forces the barbarians' intensely obstinate hatred of foreigners to capitulate. It compels all nations, on pain of extinction, to adopt the bourgeois mode of production; it compels them to introduce what it calls civilization into their midst, i.e., to become bourgeois themselves. In one word, it creates a world after its own image.

\section{- Karl Marx and Friedrich Engels, The Communist Manifesto}

Marx and Engels were right as far as they went, and they'd probably be the first to welcome the criticism that their formulation did not fully appreciate the power of the dialectic they hypothesized. European countries lost money on the China trade until the middle of the nineteenth century. Their well-heeled consumers demanded luxuries such as tea, spices, art, crafts and porcelain 
('china') while Chinese elites, with the help of government trade restrictions, found little worth buying from Europe. In 1793, the Qian Long Emperor rebuffed a British trade delegation led by Lord McCartney, writing with infinite and perhaps ironic condescension to McCartney's boss King George III: 'If I have commanded that the tribute offerings sent by you, O King, are to be accepted, this was solely in consideration for the spirit which prompted you to dispatch them from afar...As your Ambassador can see for himself, we possess all things. I set no value on objects strange or ingenious, and have no use for your country's manufactures.' Foreshadowing US-China trade today, Britain ran up a significant trade deficit with China, and silver began to flow east to cover it. British compradores finally did identify a commodity that would create its own high demand in China, and Chinese efforts to prevent the trade resulted in the disastrous Opium War. ${ }^{1}$ Having literally battered down the walls militarily and politically, European and then American and Japanese merchants were soon prying open the Chinese market with all manner of cheap commodities. In the wake of the Sino-Japanese War at the end of the nineteenth century, foreigners actually began to manufacture in China.

Was the country heading for 'underdevelopment'? Here the masters would prove masterful with their resounding 'no': China would be compelled to become bourgeois too. And so it did, taking its first steps on the long, convoluted road to capitalism with surprising celerity. By 1933, the new Chinese bourgeoisie owned 67 percent of the country's industrial factories, which employed 73 percent of its industrial labour. Rural handicraft production was not devastated the way it was in India (where it prompted Gandhi's iconic promotion of cotton spinning). In the 1930s, the volume of imported goods (other than textiles) that could compete with rural handicrafts was less than 5 percent of the volume of handicraft production.

China's transition to capitalism was, of course, stopped dead by the revolution and three decades of Maoist state socialism. But beginning tentatively in 1978, and going into high gear only after 1992, national capitalism came roaring back. Completing the dialectic that Marx and Engels did not explicitly foresee, today China is battering down walls worldwide with its own cheap commodities, in the process recreating the trade surplus it ran in pre-industrial times, albeit now on an unimaginably larger, wider and more dynamic scale. The clear beneficiaries have been the Chinese state and the renascent bourgeoisie. But what about the working class?

The debate about whether globalization is good or bad for workers, in China or any 'emerging market', is not just tiresome but methodologically vexed. For example, from 2001 to 2006, average manufacturing wages in China's more domestically-oriented northeast rose 90 percent, while those in Guangdong rose only 46 percent. $^{2}$ A critic could argue that this shows that globalization is worse than import-substitution for workers. But most of the Guangdong workers were new rural migrants with almost no cash income at all before they came to their sweatshops, whereas in 2001 those in the northeast were already employed or were urban school-leavers from families with non-trivial cash incomes. Both would be right.

The debate is also misguided. Rising wages can, of course, be perfectly consistent with even faster-rising exploitation. And in practice, that is precisely what has happened in China. Manufacturing profits in China's most globalized areas and sectors along the coast have risen far 
more than in other parts of the country. This suggests that the surplus value produced by these workers in the globalized sector has surely been far greater than in the domestically-oriented industry, and that it has provided the major material basis for the explosion of the Chinese economy and its new bourgeoisie.

And yet the working class' ${ }^{3}$ political response to globalization at the point of production has, on the whole, been broadly acquiescent in two senses. First, workers have almost never challenged the profound structural transformation from state socialism, under which they had achieved considerable power on the shop floor and material benefits, to capitalism that has deprived them of both and, indeed, driven millions into unemployment. This is all the more striking in view of the definite and often genuine radicalism of working class politics in the Maoist period. ${ }^{4}$ Second, while strikes and demonstrations have occurred, they have only involved a very small portion of the working class, and have almost never produced protest waves linking up workers beyond their factory walls.

Yet the question to ask is not whether working class contention in China represents heroic working class action, however sporadic, in the face of a repressive state in a country that utterly lacks any space for self-organization of civil society, or, by contrast, disappointing proletarian capitulation and defeat. Whether the glass is part empty or part full is a matter shot through with too much ideological, political and even psychological predisposition. The more methodologically possible and analytically appropriate questions are to do with the nature of working class resistance their participants, issues, discourses, repertoires and loci. And to home in on the effect of globalization, these questions can be raised in comparative analysis of China's more and less globalized sectors, locales and enterprises.

There is a further and often unacknowledged methodological difficulty here. Such an analytical strategy must be able to distinguish the effects of globalization from those of the wider process of structural 'reform's of the Chinese economy, of which it is only a part, albeit a crucially important one.

To attack this problem, we will compare labour politics in three regions: the highly globalized southeast 'sunbelt', the relatively less 'reformed', barely globalized, and decaying Manchurian rustbelt, and the broadly 'reformed' but only partially globalized and still largely domestically-oriented areas that make up most of the rest of the country, represented in this chapter by the city of Tianjin, site of the author's field research. For each, we will identify key dimensions of labour politics. They can be summarized as follows: 


\begin{tabular}{|c|c|c|c|c|c|c|}
\hline $\begin{array}{l}\text { Regional } \\
\text { political } \\
\text { Economy }\end{array}$ & $\begin{array}{l}\text { Resistance/ } \\
\text { quiescence }\end{array}$ & Participants & Locus & $\begin{array}{c}\text { State } \\
\text { presence }\end{array}$ & $\begin{array}{c}\text { Size \& } \\
\text { cellularity }\end{array}$ & $\begin{array}{l}\text { Dominant } \\
\text { discourse }\end{array}$ \\
\hline $\begin{array}{c}\text { Globalized } \\
\text { despotism } \\
\text { (e.g, } \\
\text { Southeast) }\end{array}$ & $\begin{array}{l}\text { Broadly } \\
\text { quiescent } \\
\text { with } \\
\text { some } \\
\text { resistance }\end{array}$ & $\begin{array}{l}\text { Younger } \\
\text { migrants }\end{array}$ & Factory & Lower & $\begin{array}{l}\text { Smaller, } \\
\text { mainly } \\
\text { cellular }\end{array}$ & $\begin{array}{l}\text { Wages and } \\
\text { working } \\
\text { conditions }\end{array}$ \\
\hline $\begin{array}{l}\text { Decaying } \\
\text { rustbelt } \\
\text { (e.g, } \\
\text { Northeast) }\end{array}$ & $\begin{array}{l}\text { Broadly } \\
\text { quiescent } \\
\text { with } \\
\text { some } \\
\text { resistance }\end{array}$ & $\begin{array}{l}\text { Older, } \\
\text { laid-off and } \\
\text { retired } \\
\text { state } \\
\text { sector } \\
\text { workers } \\
\end{array}$ & $\begin{array}{l}\text { Government } \\
\text { offices } \\
\text { and } \\
\text { public } \\
\text { spaces }\end{array}$ & Higher & $\begin{array}{l}\text { Larger, } \\
\text { mainly } \\
\text { cellular, } \\
\text { tendency } \\
\text { toward } \\
\text { metastasis } \\
\end{array}$ & $\begin{array}{l}\text { Right to } \\
\text { benefits; } \\
\text { more } \\
\text { politicized }\end{array}$ \\
\hline $\begin{array}{c}\text { Mixed, } \\
\text { adaptive } \\
\text { (e.g, Tianjin) }\end{array}$ & $\begin{array}{l}\text { Broadly } \\
\text { quiescent }\end{array}$ & - & - & Higher & - & - \\
\hline
\end{tabular}

Taken together, this political configuration forms our explanandum. The next section fleshes it out region by region. The following section attempts to explain these salient similarities and differences, focusing on the key question of labour's level of resistance, in terms of the nature of the prevailing political economy, sociological factors such as generation and social space, and the role of the state.

\section{Labour Politics: Three Patterns}

\section{THE SOUTHEAST: GLOBALIZED DESPOTISM}

In the vast majority of export-oriented firms of southeast China, there is labour peace. Most of the workers are young rural migrants, many female. They tend to come from poorer villages and towns where there is little gainful employment in agriculture or local industry to be had. The modal pattern is that they stay for a few years after leaving middle school, remitting income back home. When the time comes for them to marry, they often return home, since it is difficult to find a spouse in the city, especially one with an urban household registration without which it is difficult to establish a working and social life there over the long term. Generally these late teenagers and early twenty-somethings are (ware)housed in dormitories on factory grounds. They often work long shifts of ten or twelve hours a day, six or seven days a week. Most of the factories do not have branches of 
the state-run All-China Federation of Trade Unions (ACFTU), Communist Party committees, or worker representative assemblies - the standard complement of political institutions in state- and collective-sector firms.

The regime of accumulation is the despotic capitalism resembling in many respects that of Marx's day. Firms both smaller and larger operate within a highly competitive, largely unregulated environment. They are pressurized by ease and low costs of entry, 'just in time' technology, rapidly shifting demand, and intense pressures from buyers, including monopsonistic ones like Wal-Mart (for which firms have been known to produce for significant periods at a loss since the alternative is shutting down altogether). This makes for a highly draconian regime of sweated labour, as capital struggles for every possible quantum of surplus value. Piece-rate and overtime wage systems are carefully calibrated. Tight discipline is maintained through the dormitory system, intensive surveillance on the shop floor, strict regulation of bathroom and meal breaks, and the like. Workers are often required to put down hiring deposits in order to minimize turnover. Safety takes a back seat. Factory doors are kept locked, which has caused significant casualties when fires have broken out. $^{6}$

When it occurs, labour conflict here is generally focused on the material struggle over pay and labour process, i.e., between labour and capital over surplus value. Protest has often taken legal forms such as mediation, arbitration and litigation (Lee, 2007: 176-191). But it has also turned into contentious wildcat strikes, which of course are illegal. These normally occur in a cellular fashion, factory by factory, though there have been a small number of incidents in which workers in nearby factories demonstrate briefly in solidarity. Only rarely have they become politicized in the sense of expanding their terrain, much less their target, to the local government. In one typical case, management instituted a new time card system to help advance its position in the struggle within the economy of labour time by requiring workers to punch out and in at lunch time. This cost workers a precious ten minutes on either end of what had only been a thirty-minute break, essentially reducing their free time by two-thirds to a mere ten minutes. So they struck, demanding their time back and then expanding their agenda to a demand that the firm also observe minimum wage and overtime laws. Thousands of workers were involved, the strike lasted five days, at one point the manager was nearly beaten, and several strikers were arrested. In another case, in 2005 and 2006 management responded to successive rises in government-set minimum wage by jacking up production quotas, taxing workers beyond human endurance limits. When in 2007 the government did not again raise the minimum wage, and workers did not receive their expected annual raise, they struck in their thousands (Chan and Pun, 2009).

\section{THE DECAYING NORTHEAST}

Manchuria was China's first heavy industrial heartland. Japan invested in large factories there as early as the end of the nineteenth century, after it won the right to do so in the 1895 Treaty of Shimonoseki that concluded the Sino-Japanese War. The Maoist state continued to build it up, featuring two of its enterprises - the Anshan Steel Works and the Daqing Oilfield - as national 
models. Under the structural reforms, gargantuan state enterprises such as these did not fare well. In the 1980s their management and supervising ministries, ambivalent about the radical changes being mooted, and continuing to face only timid economic incentives and, in terms of the all-important price structure, actual disincentives to transform themselves, to were slow to adapt. They also continued to maintain the Maoist period's relatively thick presence of party and neighborhood committees, union offices, and worker representative assemblies. By the 1990s, when globalization of the Chinese economy took off, most were not in a position either to attract significant foreign investment or to produce exportable products (such as the high-tech specialty steels rolling out of South Korea). As cheap input prices set in the Maoist period to promote heavy industry were gradually freed to market levels, as government subsidies for their losses dried up, and as these firms continued to struggle under the weight of providing extensive social welfare benefits for their aging work force, they began to shed labour through layoffs and early retirement buyouts. ${ }^{7}$ Downsizing and bankruptcies became rife. Some managers, seeing the writing on the wall, quietly stripped their enterprises' assets and salted away or made away with the proceeds.

This toxic mix of a dying industrial heartland that was once the pride of the country, and the incompetence, laziness or dishonesty of its bloated management and political apparatus, has produced among workers both overarching despair leading to grudging silence, but also fury that has fueled the largest and most politicized proletarian protests in China in recent years, and the only ones that seriously threatened to metastasize into potentially destabilizing protest waves. In March of 2002, when China's National People's Congress was holding its annual session, tens of thousands of laid-off workers in Heilongjiang Province's Daqing, the oilfield that was the Maoist-era model of industrial development from which the whole country was exhorted to learn, protested arbitrary cutbacks in their already paltry severance packages. They blocked a railway and laid siege to the PetroChina headquarters. Unprecedented solidarity demonstrations were held at the Liaohe Oilfield in neighboring Liaoning Province, but also much further afield at the almost equally famous Shengli Oilfield in Shandong and clear across the country in Xinjiang. An alarmed government called in not just the armed police but a proper army tank regiment.

Simultaneously, next door in Liaoning Province over 10,000 workers of the Liaoyang Ferro-Alloy Factory took to the streets and public squares demonstrating against wage arrears and benefit shortfalls resulting from alleged management misappropriation of funds that had led to the plant's bankruptcy. They were soon joined by thousands of workers from several other failing Liaoyang plants, another largely unprecedented and, for the government, dangerous development. Moreover, the protests went beyond the original demonstrations' economic demands by becoming overtly political, demanding the dismissal of Gong Shangwu, the former Liaoyang mayor and Party secretary who was at that very moment representing the city at the National People's Congress in the capital. Even after the large initial protests were brought to an end with a combination of carrot and stick - specifically, economic concessions plus arrest of the protest leaders - significant protests dragged on for months demanding the release of the imprisoned workers. In the successive weeks, thousands of miners in Fushun and Fuxin, also in Liaoning, threatened to block railway lines in 
protest of the terms of their forced retirements. The government turned out the armed police in both cities. $^{8}$

\section{Adaptive Tianjin and Beyond}

Tianjin is broadly similar to many other parts of China in which much of the old state socialist sector has managed to adapt to the structural reforms through managerial and technological upgrading and the formation of joint ventures with foreign firms. New private or mixed-ownership enterprises, some Chinese and some foreign-invested, have also developed. Foreign investment has focused on production for China's internal market as well as for export. That helps make the economic environment for capital - and therefore for labour - less intensely competitive and pressurized than in the southeast. To be sure, economic restructuring has led to layoffs, early retirement buyouts, and factory closures or consolidations. But on the whole the economy has been buoyant enough to provide a way out for many affected workers. Some have taken jobs in the expanding private or foreign sector, while others have become self-employed. Indeed, workers in state-run firms that have gotten into economic difficulty due to the structural reforms generally see globalization as holding out hope for a foreign investor to save their plant. Older laid off or prematurely retired state sector workers who have been unable to find work have usually managed to scrape by, often by relying on help from grown children, who are, in turn, generally earning enough in the growing economy to support them. Moreover, the city government has had sufficient resources to support the cost of benefits promised to such people. For all these reasons, the level of labour protest in Tianjin and places like it is lower than in the northeast or the southeast.'

\section{Labour's Responses to Structural Reform and Globalization: Three Patterns}

Overall, then, the Chinese structural reforms have produced distinct patterns of capitalist development, which have in turn shaped different labour responses. The level of globalization appears to be a major explanans but in fact may not be the most important one. First, a highly globalized, export-oriented, hyper-competitive economy, centered in the southeast has produced a despotic labour regime relying on migrant labour. In turn workers have responded with broad quiescence punctuated by legal measures as well as mainly cellular, enterprise-based strikes and protests focusing on bread-and-butter issues and discourse. This complex concatenation can be encapsulated by the shorthand 'despotism.' Second, in what might be called 'decay', a failing state-run, import-substituting, heavy industrial sector, characteristic of the northeast, has left a labour force of younger, middle-aged and older workers facing unemployment and the prospect of surviving primarily on meager state benefits. This too has produced broad quiescence alongside occasional large, more politicized, and, briefly, metastatic protest when jobs were lost or unemployment benefits reduced. Third is an 'adaptive' pattern. Here a mixed economy of state and collective enterprises that have managed to adjust to the new market forces on the one hand, and 
newer private or joint-venture enterprises, some Chinese and some foreign funded, on the other, has developed. It relies both on internal and export markets. In places like Tianjin, it has produced solid growth without the cutthroat competition driving capitalists to sweat labour. Workers have enjoyed a smoother transition, avoiding both being abused and cast aside. The adaptive pattern has therefore engendered a lower level of labour protest than despotism or decay.

Put this way, the analysis is in danger of excessive, potentially vulgar materialist explanation. In fact, a complex set of economic, social and political explanans are also at work in producing the explanandum of labour's response.

\section{Economic Factors}

\section{DESPOTISM}

Labour has responded simultaneously in three apparently contradictory ways to globalization-driven despotism in China. Workers have lapped it up, as millions upon millions of rural migrants have streamed into the urban export platforms clamoring for work. They have for the most part endured the drudgery and degradation of the work with grudging though generally uncomplaining acquiescence. And they have occasionally fought back, and even sometimes lashed out, in a small number of cases of egregious abuse. Most generally and abstractly, the theory of exploitation explains why workers submit 'freely' to 'wage slavery'. First, they are driven into the wage relationship by economic compulsion, and then the fact that exploitation takes place in a 'hidden abode' helps obfuscate the asymmetry between labour and capital. What they see is, as the neo-liberals emphasize, their higher incomes. What neither they nor the neo-liberals see nearly as clearly, if at all, is the surplus value appropriated from them. This helps explain why Chinese migrants have flocked into the draconian world of despotic capitalism and suffered there mostly in silence.

What Marx was perhaps less good at grasping was the conditions under which workers would actually resist. He seemed to think opposition would emerge organically out of the dialectic of the capitalist labour process (which forces workers to co-operate the factory, leading to wider cooperation), the homogenization of social life, and capitalist crisis. There may be some truth to all of this - workers learned to unionize and form rich working class cultures and solidarities in many countries, especially at moments of crisis - though their resistance was generally neither revolutionary nor powerful enough to win significant gains. But this approach is also too general. What is implicit but perhaps not sufficiently explicit in Marx's theory is the proposition that working class resistance requires that the process of exploitation, which is normally opaque, become transparent. In Chinese despotic, globalized capitalism, what has set off resistance is not the quotidian misery of factory life itself, but a series of events that drag exploitation from its 'hidden abode' out into the open. In the first case discussed in these pages by Pun Ngai, workers who did not resist the appropriation of surplus value day in day out nonetheless rose to their feet and found their voice when, in the usually obfuscated struggle over labour time, they lost twenty out of thirty 
minutes they had previous had. In the second case, they became incensed when management stopped its practice sharing some of its increasing profits (grounded in growing amounts of appropriated surplus value from productivity gains) with the workers, leaving them with a precisely measurable decline in their expected income. It is only at that point that workers can, as Pun shows, take advantage of the way the labour process and the social and cultural spaces created by despotic capitalism enabled workers to act collectively. Put the other way around, unless the exploitation was made transparent, the highly exploited migrant workers of Shenzhen would in general continue quietly to turn out masses of surplus value.

Such abstract theory can help explain, then, why migrants flock to, generally acquiesce in, but also occasionally resist dreadfully despotic labour in China's globalized south. It is worth noting that globalization is not intrinsic to the theory. It could and does apply just as well to domestic despotic Chinese firms producing for the home market. Rather, the theory has implications for globalization, by pointing out the conditions under which workers seek, endure and may resist it. Specifically, where, as in south China, globalization produces intense levels of competition that induce capital to take a despotic measures on the shop floor that bring exploitation - the extraction of surplus value - into the open, it is more likely to produce resistance.

\section{DECAY}

The material basis of working class protest under conditions of economic decay is utterly different. Like workers everywhere living amidst rapid economic decline, the Manchurian proletariat would love to be exploited in regular work, and those who manage to cling to the opportunity are generally uncomplaining about it. Resistance has occurred mainly when work has disappeared, workers have had to settle for being merely sustained at a subsistence level by the state, and that sustenance has been threatened. Here moral economy has more explanatory power than Marxist political economy. E. P. Thompson and James Scott have theorized respectively that resistance in early capitalist and peasant societies flows mainly from the revocation, forced by rising market forces, of preexisting moral codes that protected poor working people for centuries. And the resistance tends to turn quickly to rage because of both the moral element as well as the material fact that those who relied for their very lives on the traditional protections - likened by Scott to people up to their necks in water - now face the prospect of disaster. ${ }^{10}$

State socialism guaranteed the working class employment and the modest wages and comprehensive benefits that came with it. Workers came to regard their work and income as a moral and political right provided by socialism. With the advent of the structural reforms, they had little or no way to provide for themselves without such employment. Some were too old. For those still of working age, the local economy was in crisis, and they certainly could not afford to move away and lose their factory-supplied housing, however miserable it was. All this can help explain why the protests occurred when they did, at a moment when the last vestiges of these state socialist rights were being withdrawn, and also why they so quickly reached a high dudgeon of moral and political fury not seen in the strikes in despotic southern factories. It can also contribute to an explanation of 
the higher level of politicization of protest. In the decaying northeast, the moral and political right to stable employment and livelihood was created by the revolution and the socialist state, and thus could only be withdrawn by that state. And in material terms, even former workers depended on the state for their retirement or unemployment benefits, housing, health care, and education for their children or grandchildren. Finally, this theory sheds light on the metastatic tendency of protest under decay. Since the moral and political right and set of material benefits had been provided to all workers and former workers, its withdrawal affected a broader swath of the local working class.

Returning to the question of globalization, decaying areas like China's northeast are, as we have noted, only weakly linked at best to the international economy. Globalization may be considered responsible for the situation only at several removes: once the Chinese economy opened to the world, much of its former state socialist sector could not compete. Or it could only compete by abrogating the state socialist labour regime of guaranteed employment and benefits. In China, labour market reform was pioneered by foreign-invested firms (Gallagher 2005). But globalization is only one factor responsible for the decay of former state-owned industry. These firms proved unable to adapt to the new marketizing environment introduced around 1980, long before they actually began to face direct global competition. And even if they had been healthy and efficient, in the 1990s they still would have laid off workers whether they needed to or not: in a stunning example of the stubborn commandist bureaucratism that still plagues China, in recent years profitable, prosperous state-owned enterprises in China's central coast have followed orders to lay off workers even if they did not have labour surpluses (Hurst 2009). In Chinese industry layoffs and restructuring more generally often have their own inner origins that are not attributable to globalization, or even for that matter to economic forces.

\section{ADAPTATION}

In places like Tianjin, the lower level of labour resistance to globalization and to structural reform more generally is due, as we have seen, in part to the capacity of the economy to generate enough alternative employment and modalities for taking care of the unemployed. But there is something deeper and more structural as well. Many former employees of state enterprises especially those in struggling firms where pay is low and security questionable - actually experienced their layoffs positively. They appreciated the opportunity to choose their own work. Some welcomed the tradeoff of working in a globalized firm, with its more arduous pace and even draconian shop floor regime, in return for higher pay. This includes both those who left willingly or greeted their layoff with equanimity as well as those who feared being left flat but prayed successfully for an international investor to buy out their dying state enterprise. Others appreciated the existential benefits of self-employment, even if that meant just driving a taxi. ${ }^{11}$ From the point of view of many workers in adaptive economic environments, structural reform and globalization, while not ushering in a neo-liberal nirvana, did in the end provide a welcome enough departure from the cosseted but limiting world of state socialist employment. For them, resistance was the furthest thing from their minds. 


\section{Social Factors}

\section{GENERATION}

The young migrants employed in southeastern despotism were born in the 1980s, when the iron rice bowl' of guaranteed employment and social welfare was already being consigned to the scrap heap of history. Having heard about it from their parents or grandparents is, of course, not nearly enough for them to develop a full appreciation of what it meant, much less to experience their working lives as a loss of such proletarian rights, privileges or victorious spoils. Moreover, the accounts of the state socialist past that have come down to them are just as likely to include horror stories or dark whisperings about the Cultural Revolution. For them there is little if any 'radiant past' (Burawoy and Lukács 1992). Instead, their world is one of purer economic calculus, to which they react, as we have seen, with a mixture of acquiescence and occasional protest, both of which are grounded in the wage relationship.

By contrast, there most certainly is a 'radiant past' for the cashiered workers of the decaying northeast who find both themselves and their iron rice bowls on the scrap heap. Indeed, in a world that has become utterly devoid of the work, livelihood, routines, cultural values, social solidarities and political triumphs and struggles of their formative years, these workers have little left but the past. Little wonder, then, that they react strongly and politically when its last remnant - a miserable severance package - is pilfered.

The younger workers in adaptive political economies have a similar existential outlook to their generational cohort in the southeast. What they have much less of is the despotism to drive them from acquiescence to protest. And while many of their parents and grandparents, especially those unable to find or undertake work, may look back longingly for their iron rice bowls, they are less likely than their Manchurian cohort to have lost it utterly. Moreover, they are, if necessary, more likely to be able to fall back on the support of their own grown children, which is much more difficult in the decaying areas where their progeny are also having trouble making ends meet.

\section{DANWEI (WORK UNITS) AND SOCIAL SPACE}

The Maoist-era danwei, in which the state organized the urban population into work-based communities that provided employment, social services, welfare, social life, and political supervision and organization, proved to be a double-edged sword. It enabled the state to supervise the population and keep them dependent, which promoted political acquiescence and often even loyalty. But at moments of crisis the danwei also provided a ready source of solidarity that could fuel protest while also rendering it cellular. Whether during the Cultural Revolution, the 1989 anti-government protests, or the 1999 anti-American protests against the bombing of China's Belgrade Embassy, protesters tended to march under banners of their work unit.

In the despotic factories of China's globalized southeast, work units are gone, but they have been replaced by enterprises in which workers are often required to live in dormitories and eat in factory canteens. And while the Maoist danwei combined political appeals and mobilization as well as surveillance and control, factory managers, concerned almost exclusively with economic 
control of their workforce, do not maintain such a political apparatus. It may be more likely, then, that, in comparison with the Maoist-era danwei, the social space of the despotic factory dormitory and refectory can serve to promote the development of protest when the right catalyst - which, after all, affects all firm employees in the community equally - comes along. ${ }^{12}$

In the decaying northeast, especially the company towns like Daqing, cashiered workers generally still huddle together with their former fellow workers in their old enterprise-supplied housing. Some of the old danwei apparatus, such as clinics and dining halls, have fallen into disuse or gone commercial. And while the political apparatus of neighborhood committees often still functions, under the general depoliticization they exercise much less control and engage in less mobilization than they did in their glory days. In functional terms, the situation is broadly similar to that of the despotic dorms: people with identical relationships to the political economy are concentrated in tight, exclusive social spaces where state political surveillance and control are somewhat loose. And the potential implications for facilitating protest are congruent as well.

In adaptive settings like Tianjin, the old danwei have been more thoroughly eliminated. Much enterprise housing has been privatized or demolished. As a result, most people no longer live surrounded by their present or former co-workers. Of course such a situation is much less conducive to the development of collective resistance.

\section{POLITCAL FACTORS}

Here just a few well-known points can be noted. The market Leninist state's ongoing monopoly of all political space - its strict prohibition against any self-organization of civil society both hinders collective resistance and, when protest does occur, leaves it leaderless and disorganized while also driving it into the pervasive cellular pattern. Where, as in the decaying Manchurian towns in 2002, spontaneous resistance nonetheless threatened to metastasize, the state acts quickly and firmly, putting thick force on the ground. These are formidable obstacles indeed to labour protest.

All that to the contrary notwithstanding, the state has also taken a somewhat measured approach to most protests. The vast majority of striking or demonstrating workers are not arrested or called in for political questioning - only their more obstreperous leaders are, even in cases of cellular protest (which comprise the vast majority). And the government generally also responds with material emollients to meet at least some of the protesters' demands. This of course tends to encourage protest. A new ditty has arisen among disgruntled workers: 'If you make a small ruckus, you'll get small result; make a big ruckus and you'll get a big one.' But the state's approach also discourages protest leadership, further driving resistance into the familiar wildcat, spontaneous pattern that quickly burns itself out. The state has shrewdly calculated that it is better off allowing protest that it can manage than trying to stop it altogether with hard repression and tight surveillance. The latter might well be impossible, and would run the risk of producing a broad backlash. Moreover, allowing protest provides the state with a way of learning about egregious hotspots so it can cope with them by rooting out avaricious or ineffective leaders while also providing aggrieved citizens with some mollifying resources. 


\section{STATE REACTIONS}

We have already begun to explore the question of how the state responds to labour's resistance to structural reform and globalization. In addition to tolerating protest, it has tried with some success to embed labour relations, in both domestic and foreign firms, and in enterprises producing both for Chinese and international markets, in a framework of legislation. And it has also lately begun to try to control the situation through expansion and reinvigoration of China's moribund state-run labour union.

The legislative approach began in 1995 with a comprehensive labour law. It stipulated all manner of regulations on working conditions, hours and overtime, while also assigning to the ACFTU the responsibility of reaching collective contracts between employers and employees (of which more anon). To this it added mediation and arbitration channels that have seen increasing uptake from aggrieved workers. From 2003 to 2006, the number of disputes settled by arbitration increased from 95,800 to 141,500 , while the number settled by mediation rose from 67,800 to $104,000 .{ }^{13}$ In 2004 the National People's Congress passed the country's first minimum wage law. And in 2008 it introduced a controversial Labour Contract Law, opposed by many employers, including international firms, who lobbied against it because it gave workers rights to longer-term contracts and protections against arbitrary dismissal. Even some academics who claimed to have workers' interests at heart opposed it, arguing that it would only benefit the better-off workers who didn't need such protection anyway, while endangering the less skilled, whom employers were now more likely to fire just before they reached eligibility for protection.

The rise of legalism in labour relations has had several purposes. It is a genuine attempt to rein in the most egregious labour practices, thereby preempting serious disputes, normalizing factory life, and proclaiming to workers that the government is looking out for their interests. It has also been intended, with some success, to canalize and individualize disputation - to drive it from strikes and demonstrations in the factory and streets toward arbitration and mediation in government meeting rooms. It has functioned to provide angry workers with an organizing and legitimating tool. By citing the law, they become more convinced that they are justified, more able to persuade others, more confident, and thus bolder. Legalism also sets up the protagonists in a way favorable to the state, as workers cite central government documents as weapons against their managers and local government officials, focusing their ire on the latter rather than Beijing. Yet as with so much of labour politics, the legalistic approach has its dangers for the state. In the end the laws are rarely enforced, which is bound to shake workers' views of the whole project and, possibly, begin to undermine the state's increasingly legalistic claim to legitimacy. ${ }^{14}$

More recently, beginning in 2006, the government seemed poised to wake up its trade union federation, Rip van Winkle-like, from a long sleep. ${ }^{15}$ The All-China Federation of Trade Unions was created in the early 1950s to bring China's myriad, autonomous and often radical labour unions government control. Many union locals were involved in the strike wave of 1957, after which they were emasculated. Thus, the ACFTU was not a significant protagonist in the working class radicalism of the Cultural Revolution. Nor has it played any significant role in mediating, much less 
advocating for or fomenting, labour protest under structural reform. In most cases, workers with grievances serious enough to send them into mediation, arbitration, strikes, or the streets have not even bothered to seek support from their labour union branches along the way. Insofar as the union makes any systematic effort to prevent, preempt or canalize conflict, it is only in arranging and administering collective contracts between workers and employer. The union's other major role vis-à-vis labour politics is to monitor it, which it discharges through surveys of workers' opinions and writing reports when problems flare up. And of course there are the quaint functions, left over from Maoist days, of organizing leisure activities and minuscule welfare funds for injured workers, holiday parties and the like.

In much of the export-oriented sector, unions still do not even exist. The ACFTU has had difficulty keeping up with the efflorescence of new industrial enterprises since the start of the structural reforms in 1978, and especially since the Chinese economy and transition to capitalism, including labour market 'reform', took off in 1993. ${ }^{16}$ Foreign firms that employ Chinese labour either directly in their own firms or indirectly through Chinese firms with which they contract divide into two broad categories in their approach to this situation. Those from countries with despotic systems of labour relations - which tend to include those from Hong Kong, South Korea and Taiwan - naturally welcome it. The absence of genuine labour union organization was often a significant consideration in their decision to come to China in the first place. Some South Korean firms in particular did so in part to escape an environment of increasing challenges from their working class at home. On the other hand, for firms accustomed to dealing with labour unions in their home countries - which tend to be those from the West and even Japan with its enterprise unionism - Chinese unions serve the valuable role of streamlining and regularizing labour relations. As we have seen, the 1995 Labour Law specifies a major role for ACFTU branches in arranging collective contracts with workers. These firms find collective contracting attractive since it saves them the administrative trouble of offering, inking and implementing contracts with each individual worker. Having unions in their plants can also help them receive social accountability certifications such as SA 8000, which are required by some major Western retailers (Ngai 2003). It is all the more beneficial for such employers that Chinese unions generally do little or nothing to enforce those contracts.

The new leadership that came to power in 2002 and 2003 under President Hu Jintao and Premier Wen Jiabao placed more emphasis than Jiang Zemin had in the 1990s on the growing inequalities and irritants that have caused a rising drumbeat of protest during China's transition to capitalism. Their ideological mantra has been the creation of a 'harmonious society'. They thought that resuscitation of the country's trade unions, especially in the foreign-invested sector, would help stabilize and monitor labour relations. But if it was intended to provide a counterweight to the most exploitative labour practices there, they began in the wrong place by taking on major international corporations, who were generally China's best foreign employers. In October, 2004, the ACFTU published a 'blacklist' of global corporations - including Wal-Mart, Dell, Eastman Kodak, McDonald's, and Samsung - that forbade the establishment of unions. It quickly lighted on Wal-Mart, the international paragon of anti-unionism, as its first victim. After a long and complex 
battle, in which the ACFTU deployed mass mobilization tactics that the Communist Party had not used since the revolution, identifying pugnacious Wal-Mart employees and encouraging them to take the lead, by fall 2007 all Wal-Mart stores in China had union branches. In September 2008 it announced a further campaign to replicate the feat in all factories of Fortune 500 companies in China within the space of one month. The latter program fizzled, a victim of excessive goal setting and, no doubt, the worsening worldwide depression.

Perhaps the ACFTU started with the biggest and best foreign employers because they were low-hanging fruit. At least some such firms had experience at home working with labour unions, though that was surely not the case with Wal-Mart. Perhaps the ACFTU counted on the fact that these companies, aware that they were already relatively good employers by Chinese standards, would not feel they had much to lose. Perhaps it was just looking to score some cheap propaganda points that would win favor with the Chinese people, to whom it was increasingly appealing for legitimacy on nationalistic grounds. ${ }^{17}$ To be sure, going after these gargantuan firms would be a great deal easier than tackling the thousands upon thousands of smaller manufacturers in the export sector, many of whom were cosseting or were cosseted by local government officials. It could well have strategized that starting with the great firms would make going after the others easier - in Chinese parlance, 'killing the chicken to scare the monkey'.

In the event, both the chicken and the monkey emerged unscathed; the only victim was the Chinese working class. The Wal-Mart unionization drive may have appeared to introduce something new and volatile: the mobilization of genuine worker militancy by the state. But the reality proved all too depressingly familiar. Within months, most Wal-Mart union branches came to be dominated by management, its objective ally in the local Party branches, or both. Some dispirited worker activists cried out in their blogs to 'save the Wal-Mart union!'. Others accused their democratically elected union branch leaders of corruption, authoritarianism and sloth. As early as March 2008, Han Dongfang, a leading advocate for workers' rights, was driven to abandon his earlier hopes, arguing that the Wal-Mart unions were mere window dressing. In the Nanchang Bayi Wal-Mart, Gao Haitao, an ordinary worker and elected union committee member, began militating when Wal-Mart shifted the cost of new year bonuses to the union and treated its required contribution to the union of 2 percent of the payroll as a loan. Wal-Mart pressured the Nanchang city-level union office to silence Gao, and also tried to create an alternative union committee under its control. Gao beat them back with his self-taught knowledge of the law and support he enlisted from the central union offices in Beijing. Membership in the Nanchang Bayi union soared, and workers began to organize their own fund to defend Gao and their union. Wal-Mart outfoxed Gao, though. In July 2008, it concluded its first collective contract with the local in Shenyang in northeast China, an area where workers were likely to be more compliant and the party apparatus more conservative and in firm control. It provided for a 9 percent wage increase to come into effect only a year hence, at a time when foodstuff inflation in China was running between 20 and 30 percent and urban wages were rising an average of 18 percent. Wal-Mart then sought to impose this contract on all its workers. Gao Haitao fought this move, but Wal-Mart bypassed him, getting a union chair from another store to sign the contract with Gao's local. Gao has resigned his union chair in 
disgust. ${ }^{18}$ As noted above, in China law serves to control the working class and strengthen the position of the state, not to provide an objective set of rules or level playing field for sorting out conflicts between the state and society, and certainly not between labour and capital.

\section{Conclusion}

Globalization has comprised only one aspect of the Chinese structural reforms. As such, its effect on labour is difficult to separate analytically from that of the sweeping wider changes. Moreover, globalization has been unevenly distributed over the Chinese landscape. It has alighted with a wallop along the southern and central coasts, had much more muted and attenuated effects on the old northeastern industrial heartland and much of the hinterland, and left many other places in between. Finally, even in its areas of greatest impact, the many aspects of the labour regimes that have arisen - such as the dormitory system - have not been imposed directly by international firms or globalization's pressures on Chinese enterprises. Rather, they are Chinese adaptations to the new economic institutions, opportunities and pressures. Thus it would be problematic to argue that the despotic capitalism that has emerged in hyper-globalized southeast China is a simple or pure product of globalization.

We have identified three patterns of political economy under structural reform, each of which involves a distinct impact of globalization and specific effects on labour. In the southeast, a highly competitive form of breathlessly burgeoning export-oriented capitalism has produced a despotic labour regime. In the much less globalized northeast, a decaying economy has put a large part of the Maoist-era industrial working class out of work and left it dependent on meager handouts from the state. And in other areas such as Tianjin, economic development has been solid and only partly driven by globalization, enabling a smoother transition for labour.

Though labour has been broadly acquiescent in all of these new political economies, its pattern of resistance has varied. Under despotism protest has tended to be cellular and oriented to the nuts and bolts battle over surplus value on the shop floor and in the pay packet. Under decay, resistance has been more oriented to the preservation of the last remaining shreds of labour rights created by state socialism, which have occasionally fueled metastatic protest across enterprise and geographic boundaries. In the adaptive pattern, there has been relatively less protest. While the specific economic relations have been major structural determinants of these differential labour responses, social factors (such as generation and social space) and political ones (such as the state's monopoly of organization and its carrot-and-stick policy toward protesters) have also shaped the various patterns of protest.

Finally, in the face of such protest, the state has adopted a three-pronged strategy. First, it treats outbursts with a carefully modulated combination of harshness toward protest leaders and tolerance and even reward toward the majority of protesters. Second, it has erected a legal superstructure to canalize protest and attempt to preempt it in the first place by reining in the worst employer practices. Third, it has reinvigorated state-run unionism for the selfsame purposes. 
On the whole this strategy has worked. Within a very short period of time starting in earnest in the early 1990s, China has pulled off a profound transformation in the structure of its labour relations from state socialism to the capitalist wage. A working class that more than once undertook significant, and sometimes even furious, outbursts in defense of its interests, rights and privileges under Maoist state socialism has on the whole gone quietly into this new world. Along the way many of the victims of structural reform of the state socialist political economy have actually welcomed globalization in the form of foreign investment that creates jobs, despite the often draconian terms of such employment.

The political economy of Chinese market Leninism faced the depression of 2008-09 with some important assets. The government could tap ample amounts of cash, some earned from trade surpluses and some from the country's extraordinarily high savings rate. The latter is a reminder that the country has a massive internal market the potential of which has only begun to be developed. While there were fears that its 2008 growth rate would dip to 5 percent - well under the 7 percent needed to maintain its employment rate - in the end it racked up 9 percent. Its financial system is not drowning in red ink (as so many pundits predicted it would several years ago), and large numbers of its people are not facing foreclosures and the disappearance of their life savings. Its working class has already endured structural changes far more profound than a small uptick in unemployment. Despite the pressures that globalization and the even larger domestic aspects of the country's transition to capitalism place on its proletariat, Chinese market Leninism proved better positioned to survive the 2008-09 depression than Western neo-liberalism. And globalization is only part of the reason.

\section{NOTES}

${ }^{1}$ Ironically, the British opium trade was also an early example of Westerners using some Asians to help conquer others, as Nixon's 'Vietnamization' would over a century later: the opium came from India.

${ }^{2}$ Calculated from China Statistical Yearbook 2002 (Beijing, China Statistics Press), table 5.22; China Statistical Yearbook 2007 (Beijing, China Statistics Press), table 5.26. The figures include all wages, not just those of workers. But assuming that the ratios of number of managers and workers, and of their wages, are roughly similar across provinces, the figures can provide a rough guide to the relative rates of increase.

${ }^{3}$ Of course the Chinese working class, like classes everywhere, is highly differentiated. Indeed, this chapter fleshes out many of the important differences. At this most general level of abstraction, it simply includes those who do industrial work under any sort of wage relationship.

4 See Elizabeth Perry, 'Shanghai's Strike Wave of 1957', China Quarterly 137(March): 1-27; Elizabeth Perry and Li Xun, Proletarian Power: Shanghai in the Cultural Revolution (Boulder: Westview, 1997); Wang Shaoguang, Failure of Charisma: The Cultural Revolution in Wuhan (Hong Kong: Oxford University Press, 1995). 
5 The commonplace term for the vast changes that have taken place in China since 1978 is 'reform'. It is appropriate insofar as it refers to the fact that change has been pursued gradually and without violence. But 'reform' can hardly capture the depth and breadth of the changes themselves. Since 1978 China has not merely been tinkering with, perfecting, or toning down Maoist state socialism. Something far more profound has been afoot. The country has been seeking, often successfully, to excise, root and branch, the basic elements of its Maoist polity, economy, society, and political culture. It has questioned a great deal of what went before. Its leaders and people have sought to create new forms of political authority, economic activity, social organization, and cultural expression. If revolution is defined as a 'basic transformation of a society's state and class structures' (Skocpol 1979: 4), then what China has been undergoing is no mere 'reform', but rather something that would more aptly be called a peaceful revolution. Another, perhaps less oxymoronic, term is structural reform.

${ }^{6}$ For more details, see Anita Chan, China's Workers Under Assault (Armonk: M.E. Sharpe 2001).

7 William Hurst has shown that even economically viable state-run firms in the rustbelt came under political pressure to lay off workers; see William Hurst, The Chinese Worker After Socialism (Cambridge: Cambridge University Press, 2009).

${ }^{8}$ See Lee, Against the Law, Part II; and Marc Blecher, A World to Lose: Working Class Formation in Twentieth-Century China (book manuscript in progress).

9 See Blecher, A World to Lose: Working Class Formation in Twentieth-Century China (book manuscript in progress).

${ }^{10}$ E. P. Thompson, The Making of the English Working Class (New York, Vintage, 1966); James Scott, The Moral Economy of the Peasant (New Haven: Yale University Press, 1976).

${ }^{11}$ Author's interviews, Tianjin, 1995-99. Subsequent visits and discussions with social scientists there confirm that the situation remains the same if not even more pronounced a decade on.

${ }^{12}$ Lee, Against the Law, 2007. Of course factory-based dormitory housing is not a necessary feature of globalized despotism. Managers could just as easily not provide it and allow their workers to live off-site, assuming that the housing market would deliver appropriate supply (which it surely would and often does - in China where the demand from workers exists). It is an interesting question, though, whether such off-site housing would be more or less conducive to collective mobilization.

${ }^{13}$ China Statistical Yearbook (Beijing, China Statistics Press, various years).

${ }^{14}$ On this whole complicated question, see Ching Kwan Lee, Against the Law.

15 Some of the following discussion draws upon Marc Blecher, 'When Wal-Mart Wimped Out', Critical Asian Studies 40(2): 263-276.

16 According to official statistics, the number of trade union branches in China declined from 627,000 in 1993 to 509,000 in 1999. (Statistical Yearbook of China 2003, table 23-4.) [Figures for subsequent years gyrate wildly, and are highly suspect. The source contains a footnote referring to the need for statistical adjustment in 2003.] The figures on union staff are steadier and, accordingly, more credible. They dropped from 554,000 in 1993 to 465,000 in 2003.

17 Witness its support for 2005 anti-Japanese demonstrations, the Tibet crackdown of 2008, and, of course, the Olympics. 
18 'Promising Wal-Mart Trade Union Chair Resigns Over Collective Contract Negotiations,' China Labour News Translations, September 2008.

\section{REFERENCES}

Blecher, M. (2008) 'When Wal-Mart Wimped Out', Critical Asian Studies 40(2): 263-276.

Blecher, M. (2009) A World to Lose: Working Class Formation in Twentieth-Century China (book manuscript in progress).

Burawoy, M. and Lukács, J. (1992) The Radiant Past. Chicago: University of Chicago Press.

Chan, A. (2001) China's Workers Under Assault. Armonk: M.E, Sharpe.

Chan, C. and Ngai, P. 'The Making of a New Working Class? A Study of Collective Actions of Migrant Workers in South China', China Quarterly 198(June 2009): 293-296.

China Labour News Translations (2008) 'Promising Wal-Mart Trade Union Chair Resigns Over Collective Contract Negotiations', China Labour News Translations, September 2008.

China Statistics Press (2002) China Statistical Yearbook 2002. Beijing: China Statistics Press.

China Statistics Press (2003) China Statistical Yearbook 2003. Beijing: China Statistics Press.

China Statistics Press (2007) China Statistical Yearbook 2007. Beijing: China Statistics Press.

Gallagher, M. (2005) Contagious Capitalism: Globalization and the Politics of Labour in China. Princeton: Princeton University Press.

Hurst, W. (2009) The Chinese Worker After Socialism. Cambridge: Cambridge University Press.

Lee, C.K. L. (2007) Against the Law: Labour Protests in China's Rustbelt and Sunbelt. Berkeley: University of California Press.

Ngai, P. (2003) 'Global Production, Company Codes of Conduct, and Labour Conditions in China: A Case Study of Two Factories', China Journal 54(1): 111.

Perry, E. (1994) 'Shanghai's Strike Wave of 1957’, China Quarterly 137(March): 1-27. 
Perry, E. and Li, X. (1997) Proletarian Power: Shanghai in the Cultural Revolution. Boulder: Westview.

Scott, J. (1976) The Moral Economy of the Peasant. New Haven: Yale University Press.

Skocpol, T. (1979) State and Social Revolutions: A Comparative Analysis of France, Russia and China. Cambridge: Cambridge University Press.

Thompson, E.P. (1976) The Making of the English Working Class. New York: Vintage.

Wang, S. (1995) Failure of Charisma: The Cultural Revolution in Wuhan. Hong Kong: Oxford University Press.

\section{BIOGRAPHICAL NOTE}

Marc Blecher is Professor of Politics and East Asian Studies at Oberlin College (USA). He is the author of four books and several dozen articles on Chinese politics, society and political economy, focusing on local politics and political economy in rural and urban China. The third edition of China Against the Tides (Continuum) is out in 2010. His current research focuses on working class formation in China and on the role of urban governments in north China in shaping economic development and its social consequences. He lives in Oberlin, Ohio with his wife Sharon, and spends several months each year in London. 